\title{
NAFSU BERLEBIHAN PEMBANGUN MERUSAK LINGKUNGAN HIDUP: 'Kwadran Bele' sebagai Alat Ukur Pembangunan
}

\author{
Bele Antonius
}

\author{
Universitas Kristen Satya Wacana, Salatiga \\ anton_bele@yahoo.com
}

\begin{abstract}
Abstrak
Pembangun yang membangun dengan Nafsu berlebihan, merusak lingkungan hidup. Manusia itu terdiri dari Nafsu, Nalar, Naluri dan Nurani, (4N), yang dikenal akhir-akhir ini di kalangan beberapa kawan saya dengan nama "Kwadran Bele". Di Kecamatan Lamaknen Selatan, Kabupaten Belu, Pulau Timor, Provinsi Nusa Tenggara Timur, ada 17.127 ribu orang. Mereka inilah yang memakai Nafsu berlebihan untuk membangun sehingga merusak lingkungan tempat hunian mereka secara terusmenerus dari tahun ke tahun. Akibatnya tempat mereka semakin rusak dan tidak layak huni lagi. Di tempat inilah peneliti membuat penelitian kualitatif selama empat tahun, dari tahun 2014 sampai 2018. Akar masalahnya ialah: membangun hanya terdorong oleh Nafsu, tanpa kendali Nalar, Naluri dan Nurani. Jalan ke luarnya, Manusia itulah yang terlebih dahulu dibangun untuk seimbang antara Nafsu, Nalar, Naluri dan Nurani.
\end{abstract}

Kata Kunci: Kwadran Bele, Nafsu, Nalar, Naluri, Nurani

\begin{abstract}
The Developer who develops with uncontrolled desire, damages the environment. Human being is consists of Desire, Reason, Instinct and Conscience as nowadays among some of my friends known as "Kwadran Bele" ("Bele Quadrant"). In the sub-district of Southern Lamaknen, Belu District, East Nusa Tenggara Province, there are 17,127 people. They developed their environment with uncontrolled desire so they damaged their environment and their residence contiuously year by year. The result is clear now that their land is heavily damaged and actually unhabitable anymore. In this place the researcher made a qualitative research for four years, 2014 to 2018. The root of the problem is that the people developed their environment with uncontrolled desire without considering a good reason, humanity and conscience aspects. The way-out is the people themselves have firstly to be urged to be aware of themselves as human being who develop with a sound and pure desire, reason, instinct and conscience.
\end{abstract}

Keywords: Bele Quadrant, desire, reason, instinct and conscience

\section{PENDAHULUAN}

Kecamatan Lamaknen Selatan di Kabupaten Belu, Pulau Timor, Provinsi Nusa Tenggara Timur, berbatasan langsung dengan Negara Timor Leste dengan luas wilayah $108 \mathrm{~km} 2$, di ketinggian 980 meter di atas permukaan laut, berbukit-bukit dan lahannya sangat tidak subur. Pada musim hujan dari bulan Desember, Januari sampai Maret, selama empat bulan, lahan pertanian terkuras humusnya oleh erosi setiap tahun. Pertanian dengan sistim tebas-bakar menyebabkan wilayah ini semakin gersang dari tahun ke tahun dan sumber-sumber mata air semakin kurang karena terjadi kebakaran hutan dan semak belukar yang menyebabkan matinya tanaman perlindungan seperti beringin dan pohon-pohon lain. Sistim tebas-bakar dalam bertani ini sudah dikritik oleh Ormeling (1956), enam puluh tahun lalu, sebagai pengrusakan yang sangat serius di Pulau Timor.

Kecamatan ini terdiri dari 8 Desa, 42 Dusun. Wilayah ini dihuni oleh 17.127 orang, laki-laki 8.561 orang dan perempuan 8.566 orang. Kepadatan penduduk, rata-rata 73 orang per/Km2. Orang dewasa, 17 tahun ke atas berjumlah 5.138 orang. Usia produktif, 17 tahun sampai 55 tahun, berjumlah 1027 orang. Mereka terdiri dari 1.565 kepala keluarga dengan rata-rata 4 orang satu keluarga. (Data Statistik Kecamatan, 2018). 
Gambar 1. Peta Indonesia: Propinsi Nusa Tenggara Timur

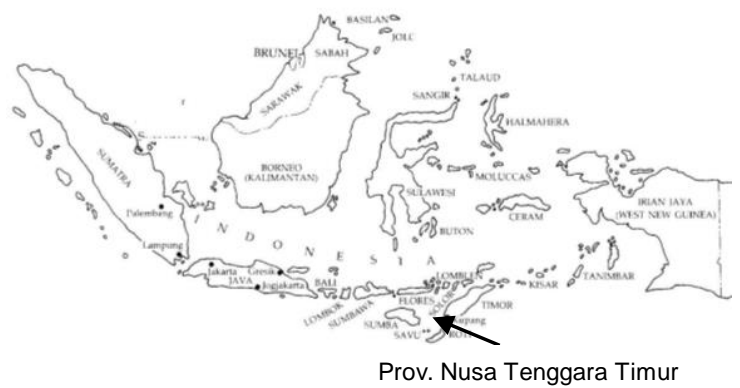

Gambar 2. Peta Kabupaten Belu: Kec. Lamaknen

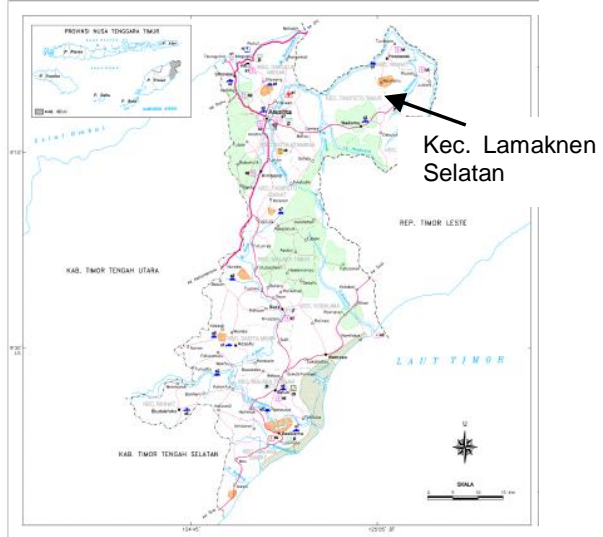

Sumber: BPS Kab. Belu, 2018

Penduduk kecamatan ini merupakan satu kesatuan suku dan bahasa. Suku mereka adalah suku Buna' dan bahasa mereka adalah bahasa Buna'. (Bele Antonius, 2011). Dalam hidup sehari-hari mereka berbahasa Buna' dicampur dengan bahasa Indonesia.

Matapencaharian dari masyarakat Lamaknen Selatan ini ialah bertani dan beternak secara tradisional. Hasil pertanian untuk dikonsumsi sendiri terdiri dari jagung dan padi ladang ditambah kacang-kacangan, labu, cabai, bawang dan ubi-ubian. Tanaman umur panjang terdiri dari jeruk, kopi, mangga dan kemiri. Hasil tanaman umur panjang inilah yang menunjang kehidupan keluarga karena dapat dijual di pasar sesudah dipanen.

Mereka memelihara sapi, kuda, kambing, babi dan ayam dalam jumlah terbatas sesuai kemampuan keluarga. Semua hasil ini tidak dapat memenuhi kebutuhan sehari-hari sehingga benar-benar mereka hidup sangat sederhana, makan seadanya dan berpakaian pun seadanya. Makan yang baik dan berpakaian baik hanya pada hari-hari pesta, baik pesta adat maupun pesta keagamaan.
Perumahan rata-rata rumah darurat berlantai tanah. Kebutuhan air bersih sangat sulit terpenuhi karena mereka bergantung dari sumur alam yang umumnya jauh dari pemukiman. Aliran listrik belum menyentuh desa-desa ini secara keseluruhan. Dari 1.565 keluarga, baru 318 keluarga atau $20 \%$ yang menikmati aliran listrik. Jalan raya antar desa dan antar desa dengan ibu kota kecamatan dan ibu kota Kabupaten belum dibangun seluruhnya sehingga arus transportasi darat masih cukup sulit.

Di Kecamatan ini ada 18 unit PAUD (Pendidikan Usia Dini), 12 SD, 5 SMP dan 1 SMK. Di bidang kesehatan, Kecamatan ini memiliki 1 Puskesmas, 4 Pustu, dan 2 Pos Kesehatan Desa. Jadi di bidang pendidikan dan kesehatan, masyarakat memiliki sarana dan prasarana yang memadai tetapi tingkat kesehatan penduduk masih rendah dengan indikator jumlah balita gizi kurang dan gizi buruk masih tinggi.

Dari segi kepercayaan, penduduknya seratus persen penganut Agama Kristen Katolik namun dalam hidup harian di samping menjalankan ajaran Agama Kristen Katolik, mereka masih mempraktekkan kepercayaan Agama Asli yaitu Agama Hot Esen yang percaya pada Yang Maha Tinggi dalam bentuk persembahan di tempattempat sakral di hutan-hutan dan batu-batu (Bele Antonius, 2011).

Masyarakat Lamaknen Selatan merambah hutan, merusak lingkungan untuk mempertahankan hidup mereka. Ternyata dengan semakin menggarap lingkungan mereka dengan Nafsu yang dianggap membangun, malah merusak lingkungan dan dengan itu mereka membunuh diri dan generasi mereka secara pasti dari hari ke hari.

Limpah terimakasih dihaturkan kepada Panitia "Seminar dan Lokakarya Kualitatif Indonesia 2019" Universitas Matana yang telah mengundang dan memberikan kemungkinan untuk mengirim hasil penelitian ini untuk diseleksi.

\section{TINJAUAN PUSTAKA}

Manusia itu terdiri dari 4 unsur: Nafsu, Nalar, Naluri, Nurani. Rumusan ini digambarkan dalam satu segi empat dibagi atas empat bahagian menjadi satu kwadran, dan ini yang dinamakan 'kwadran bele'. 
Gambar 3. Kwadran Bele

\begin{tabular}{|c|c|}
\hline NAFSU & NALAR \\
\hline NALURI & NURANI \\
\hline
\end{tabular}

Sumber: Nurani Orang Buna, 2011.

Teori ini ditemukan oleh peneliti dalam penelitian di kalangan suku Buna' ini selama enam tahun, 2005 sampai 2011 (Bele Antonius, 2011). Rumusan 4-N yang dinamakan 'kwadran bele' ini didasarkan pada telaahan pendapat dari Danah Zohar \& Ian Marshall yang mengemukakan uraian tentang empat capital yang dapat diaktualisasikan manusia dalam dunia bisnis. Empat capital itu ialah: Material Capital, Intellectual Capital, Social Capital dan Spiritual Capital. (Danah Zohar \& Ian Marshall, 2005). Menurut Danah Zohar \& lan Marshall, kalau empat capital ini diwujudkan secara seimbang, maka bisnis akan berhasil karena usaha bisnis menjadi manusiawi.

Khusus tentang Social Capital yang oleh Adam Smith pada abad 18 disebut Social Contract sebagai perekat manusia dalam membangun dan selanjutnya digagaskan lagi oleh Colenam (1990), Putnam (1993), Fukuyama (1999) dan di Indonesia dipopulerkan oleh Jousairi Hasbullah (2006), maka semua pendapat itu menjadi dasar pengkajian saya untuk beranjak ke pendapat pribadi saya bahwa hal-hal itu, material, intellectual, social, spiritual capital, bukan hanya sekedar capital, tapi bahagian atau unsur dalam diri manusia yang merupakan satu keutuhan diri pribadi manusia.

Pendapat kedua isteri-suami, Danah Zohar \& lan Marshall ini saya pahami sebagai empat hal yang dimiliki oleh manusia berupa modal (capital) yang ada jarak antara pemilik, manusia dengan hal yang dimiliki yaitu modal. Berarti, modal bisa dipakai atau tidak, tergantung pada pemiliknya. Rumusan kedua orang ini memberikan inspirasi kepada saya untuk mendapat jembatan ke arah pendapat saya, 4-N, Nafsu, Nalar, Naluri, Nurani yang diberi nama, 'Kwadran Bele' sesuai dengan gambar satu segi empat dibagi empat yang merupakan satu kesatuan.

Di kalangan suku Buna' ada suatu kesadaran untuk memiliki dan menguasai alam di luar dirinya. Manusia dan alam menyatu. Manusia suku Buna' menamakan kemampuan, dorongan ini dengan nama: Nopil (bahasa Buna', artinya: tenaga, daya dalam diri saya). Kesadaran ini ada dalam diri manusia sebagai bahagian dari dirinya dan itulah yang saya namakan NAFSU, dorongan, keinginan, kemampuan untuk berkontak malah menyatu dengan dunia materi. Manusia itu pun adalah materi dalam bentuk tubuh yang ada dalam jangkauan waktu dan ruang tertentu.

Kemampuan berpikir, mengetahui, disebut oleh suku Buna' dalam bahasa Buna': Nawas, artinya, 'dahi saya' yang menampakkan diri manusia sebagai pribadi yang cerdas, berpikiran, berpendapat dan berpengalaman yang diperoleh setiap pribadi sebagai bahagian dari dirinya. Pemahaman tentang Nawas inilah yang saya istilahkan dengan kata NALAR.

Orang suku Buna' terikat satu sama lain sebagai satu keturunan dari leluhur yang sama yang diciptakan oleh Yang Maha Tinggi dengan gelar, "Bertelinga Satu, Bermata Tunggal". Semua keturunan yang ada berasal dari 'perut' yang satu dan sama. Kata perut dalam bahasa Buna', "Nejel", saya punya perut. Setiap anggota suku Buna' harus saling menghormati, saling melindungi. Pemahaman tentang 'Nejel' inilah yang saya istilahkan dalam bahasa Indonesia, NALURI. Setiap orang yang terikat oleh tali kekerabatan, suka hidup damai, hidup aman dan hidup sejahtera. Hal ini yang masih diungkapkan oleh narasumber dari suku Buna', Bapak Moruk Ama (umur 81 tahun), "Susah sama-sama susah, senang sama-sama senang".

Dalam hidup sehari-hari, masyarakat suku Buna' selalu mengungkapkan ketenangan bathin itu dengan istilah, "Nimil", saya punya hati. Dengan istilah "Nimil" ini orang Buna' mengungkapkan perasaan senang tidak senang, bahagia tidak bahagia, bersalah tidak bersalah. Atas dasar pemahaman ini, saya istilahkan dalam bahasa Indonesia, NURANI.

Kesimpulan saya, masyarakat suku Buna' ini terikat erat dengan empat unsur dalam diri 
mereka, NAFSU, NALAR, NALURI, NURANI. Selanjutnya saya buat kesimpulan, setiap pribadi manusia itu terdiri dari empat unsur ini sebagai satu kesatuan, NAFSU + NALAR + NALURI + NURANI dan ini bukan hanya sekedar 'capital' atau 'modal' yang boleh dipakai atau tidak, melainkan suatu keharusan bahwa setiap manusia mewujudnyatakan diri dalam keutuhan antara empat unsur ini. Kalau salah satu unsur ini diabaikan, maka perwujudan diri manusia itu menjadi timpang.

Hasil kajian teoretik dengan nama 'kwadran bele' ini pada awalnya hanya disebut '4-N' (Nafsu, Nalar, Naluri, Nurani). Gagasan '4-N' dicetuskan pertama kali di Universitas Kristen Satya Wacana, Salatiga pada tahun 2011 sesudah disertasi saya tentang 'Spiritual Capital dalam Pembangunan' diuji dalam ujian terbuka program doktor studi pembangunan. Kajian yang dirumuskan sebagai '4-N' dan kemudian dipopulerkan dengan sebutan 'kwadran bele' ini dihasilkan oleh penulis di bawah bimbingan Prof. Daniel Daud Kameo, S.E., M.A., Ph.D., sebagai promotor dan KoPromotor, Marten Ndoen, S.E., M.A.,Ph.D., dengan Dr. Soegeng Hardiyanto. Ujian terbuka tersebut dilaksanakan pada tanggal 5 September 2011, dipimpin oleh Rektor Magnificus Prof. Drs. John A. Titaley, Th.D., bersama dewan penguji, Dr. Daniel Nuhamara, M.Th., Dr. Pamerdi Giri Wiloso, M.Si. dan Drs. Gregor Neonbasu, SVD., Ph.D. Rumusan '4-N' yang kemudian dikenal dengan 'kwadran bele' ini dimuat dalam buku 'Nurani Orang Buna', Spiritual Capital dalam Pembangunan', penerbit Gita Kasih, Kupang, 2011. Buku ini mendapat pengakuan Hak Cipta oleh Kementerian Hukum dan HAM pada tanggal 12 September 2017 yang dipegang oleh pencipta, Dr. Bele Antonius, M.Si., berlaku seumur hidup dan tujuh puluh tahun sesudah pencipta meninggal dunia.

Penelitian tentang 'kwadran bele' sebagai Alat Ukur Pembangunan ini diterapkan dalam dialog terbuka tentang motivasi calon pemimpin termasuk Anggota dan Calon Dewan Perwakilan Rakyat. Dialog ini dihadiri oleh 211 orang tokoh agama, tokoh masyarakat dan tokoh partai politik seKabupaten Belu pada tanggal 25 Februari 2019. Dalam dialog ini dibagikan kuesioner sebanyak 100 lembar dan dikembalikan 100 lembar.
Dalam lembar kuesioner ini ditulis:

"Menurut saya, beberapa Anggota DPR/DPRD/DPD/Caleg yang saya temui dan saya kenal baik, dalam penampilan diri, lebih mementingkan aspek* $^{*}$ : .... (Lingkari satu nomor yang menurut anda paling dominan): 1.Nafsu; 2. Nalar; 3. Naluri; 4. Nurani.

Data diri: 1. Laki-laki; 2. Perempuan; 3. Umur; 4. Pendidikan terakhir: a. SMP; b. SMA; c. Diploma; d. Sarjana; e. Magister; f. Doktor. 5. Pekerjaan: a. Wiraswasta; b. ASN; c. Anggota DPRD.

*) 1. Nafsu: utamakan materi, kedudukan, kuasa

2. Nalar: utamakan wawasan, gagasan, visi-misi

3. Naluri: utamakan keluarga, kenalan, kelompok

4. Nurani: utamakan kemanusiaan, pengabdian, kerohanian.

Sesudah dibicarakan apa itu 'kwadran bele' dan dibagikan lembaran kuesioner sebanyak 100 lembar, terisi 100 lembar, ada 8 lembar yang diisi tidak sesuai permintaan (mengisi lebih dari dua nomor), lalu 92 lembar atau 92\% diseleksi, maka hasilnya, yang memilih:

1. Nafsu, 57 orang, $61,95 \%=(62 \%)$

2. Nalar, 5 orang, $5,4 \%=(5 \%)$

3. Naluri, 9 orang, $9,78 \%=(10 \%)$

4. Nurani, 21 orang, $22,82 \%=(23 \%)$

Dari hasil dialog yang dikuatkan dengan kuesioner ini dapat disimpulkan bahwa pelayan publik sebahagian besar, $62 \%$ merebut posisi pemimpin untuk kepentingan materi, kedudukan dan kuasa berdasarkan Nafsu. Hanya 23 \% yang mementingkan kemanusiaan, pengabdian dan kerohanian berdasarkan Nurani. Lebih sedikit lagi, hanya $\mathbf{1 0} \%$ yang mementingkan keluarga, kenalan dan kelompok berdasarkan Naluri. Sangat sedikit, $5 \%$ yang merebut kekuasaan untuk mewujudkan wawasan, gagasan, visimisi berdasarkan Nalar. Hasil ini dapat diaplikasikan pada moralitas pemimpin di Kabupaten Belu termasuk di wilayah penelitian, Kecamatan Lamaknen Selatan, Pemimpin bersama masyarakat yang dipimpin sibuk membangun berdasarkan Nafsu dan tanpa sadar terhanyut pada 
urusan materi, kedudukan dan kuasa. Urusan kemanusiaan, keluarga dan keilmuan kurang mendapat perhatian.

\section{METODE PENELITIAN}

Peneliti merasa heran bahwa masyarakat di Kecamatan Lamaknen Selatan hidup aman dan nyaman dalam segala keterbatasan yang jelas terlihat dari kacamata orang luar. Maka timbul pertanyaan: Hal apa yang menyebabkan masyarakat ini masih bertahan hidup di wilayah ini sampai sekarang? Apakah tolok ukur perkembangan sosial-budaya dan ekonomi masih dapat dipakai sebagai ukuran kesejahteraan sekelompok orang? Apa saja faktor pendukung dan faktor penghambat kehidupan masyarakat ini dalam ketahanan hidup mereka di daerah yang begitu sulit? Apakah segala bantuan fisik dan non fisik dari luar dapat membebaskan mereka dari penderitaan keterbelakangan ini?

Pertanyaan sentral, hal apa yang menyebabkan mereka tetap hidup dan berjuang di daerah yang sulit ini? Ternyata mereka hidup berkelompok dalam 42 dusun dan pola hidup di dusun ini menyatukan mereka sekian rupa sehingga mereka bertahan menekuni hidup dalam segala keterbatasan. Ada unsur pemersatu. Apa unsur pemersatu itu?

Dalam penelitian ini peneliti memakai metode kualitatif berdasarkan grounded theory (Glaser \& Strauss 1967), di mana temuan terdahulu dibandingkan dengan keadaan sekarang lalu diuji dengan teori yang peneliti peroleh secara induktif. Data lapangan berupa pengamatan dan wawancara yang dihimpun peneliti, dicatat, dipilah-pilah lalu diseleksi isinya untuk dianalisa berdasarkan teori yang peneliti tetapkan sebelumnya.

Peneliti tetap berpegang pada strategi perspektif konstruktivis dalam mana pengalaman penulis dijadikan perbandingan dengan keadaan masyarakat sekarang ini sebagai acuan untuk dibuat analisa dan kesimpulan sebagai alur uraian mulai dari latar belakang sampai pada kesimpulan penelitian ini (Maryaeni, 2005). Demi menguji kesahihan teori 'kwadran bele', peneliti menguji dengan triangulasi data (Imam Gunawan, 2013) dalam dialog tentang pola perilaku pemimpin yang menunjukkan hasil, $62 \%$ pemimpin dan calon pemimpin lebih menekankan Nafsu untuk kepentingan kuasa dan harta benda dari pada pelayanan kepada sesama.

Penelitian ini dilaksanakan untuk mencari akar ketahanan masyarakat yang terlilit masalah penderitaan sosial ekonomi berupa keterbelakangan dalam bentuk kemiskinan dan kebodohan. Masyarakat menggarap lingkungan untuk memenuhi kebutuhan hidup, ternyata merusak lingkungan hidup itu sendiri. Mereka ingin ke luar dari kemiskinan ternyata dari miskin tetap miskin dan malah bertambah miskin.

Dengan penelitian ini dicari jalan ke luar apa yang paling tepat dalam mengatasi kesulitan masyarakat di wilayah Kecamatan Lamaknen Selatan untuk terbebas dari lingkaran setan kemiskinan dan kebodohan yang membelit mereka sampai sekarang. Apa yang harus dilakukan agar upaya yang namanya pembangunan diri dan lingkungan membawa hasil yang memuaskan dalam bentuk kesejahteraan lahir dan bathin.

Penelitian ini bermanfaat untuk dijadikan model dalam mengatasi masalah kemiskinan dan kebodohan di seluruh wilayah Provinsi Nusa Tenggara Timur yang sampai sekarang dikenal dengan Provinsi termiskin nomor urut ketiga dari bawah sesudah Provinsi Papua dan Papua Barat.

\section{HASIL DAN PEMBAHASAN}

Masyarakat suku Buna' di Kecamatan Lamaknen Selatan yang sekarang ada, sudah menetap di wilayah ini lebih dari tujuh puluhan tahun sesuai usia penduduk yang termasuk orang yang sudah tua. Sedangkan leluhur mereka sudah menetap di wilayah ini sejak awal tahun 1700 dengan perkiraan adanya pergolakan antar penduduk di wilayah bahagian Timur dari pulau Timor yang sekarang ini menjadi Negara Timor Leste. Peneliti sendiri sudah berusia 72 tahun dan terlahir di wilayah ini pada tahun 1947 sampai menyelesaikan Sekolah Dasar pada tahun 1959. Dalam usia 12 tahun peneliti meninggalkan wilayah ini dan tidak pernah menetap di sana. Pengalaman peneliti selama masa kanak-kanak ternyata masih sama dialami oleh masyarakat sampai sekarang, hidup susah dalam hal makanan, pakaian, perumahan, malahan mereka lebih susah lagi sekarang ini karena kesulitan air 
bersih lebih parah dari lima puluhan tahun lalu. Penelitian ini termasuk penelitian dengan pendekatan 'emic', meneliti pengalaman sendiri (Burhan Bungin, 2011).

Tanah pertanian semakin tandus. Hasil kebun berupa tanaman utama, jagung dan padi ladang, sangat kurang dan tidak dapat memenuhi kebutuhan pangan dan diganti dengan pasokan 'beras sejahtera' dari luar. Hasil ladang, padi dan jagung hanya dapat memenuhi kebutuhan selama tiga bulan, April sampai Juni. Sembilan bulan yang lain, Juli sampai Desember disambung dengan Januari sampai Maret tahun berikutnya mereka hidup dari hasil kebun berupa ubiubian dan kacang-kacangan dan bantuan beras dari Pemerintah, rastra, beras sejahtera.

Orang tua menyekolahkan anak-anak dengan menjual sapi, babi atau kambing peliharaan ditunjang dengan menjual hasil tanaman umur panjang, kopi dan kemiri yang harganya tidak seberapa. Pohon-pohon kopi dan kemiri tidak dapat menghasilkan buah secara maksimal karena tidak ada perawatan apalagi peremajaan. Pertanian dijalankan dengan cara tradisional, masih dengan cara tebas-bakar. Alat yang dipergunakan pun masih tetap dari zaman leluhur, tajak (alat seperti linggis) dan parang. Ladang yang digarap rata-rata per keluarga hanya sebatas setengah hektar.

Para pemuda dan pemudi dari Kecamatan ini lebih banyak mencari nafkah di ibu kota Kabupaten, Atambua yang jaraknya sekitar 40-an kilo meter atau di luar Provinsi NTT, entah di Kalimantan, Papua, Sumatera atau di luar negeri seperti Malaysia dan Serawak. Tenaga kerja produktif untuk bekerja di ladang, sudah sangat kurang. Dalam wawancara dengan mantan Camat di Kecamatan Lamaknen Selatan, Bapak Yustinus Bau, 48 tahun, pada tanggal 27 Februari 2019, didapat informasi:

"Masyarakat di Kecamatan Lamaknen Selatan hidup susah dari dulu sampai sekarang. Perumahan darurat yang paling banyak. Makanan seadanya. Ternak juga terbatas karena padang gembalaan untuk sapi, kerbau dan kuda, terbatas. Kalau sapi diikat, pakan ternak sangat sulit terlebih pada musim kemarau, rumput menjadi kering dan daun-daun kayu terbatas sehingga ternak jadi kurus-kurus. Karena susah hidup di delapan desa di Kecamatan ini, maka orang-orang muda banyak yang lari ke luar, ke Sumatera, Kalimantan atau Papua. Ada yang ke luar negeri, Serawak dan Malaysia. Mereka yang kerja di luar ini tidak banyak bawa perubahan karena hasil usaha di luar daerah itu tidak seberapa. Selama dua tahun saya menjadi Camat, 2016-2018, ada empat pemuda yang pulang kampung dari perantauan di luar negeri, dan mati di kampung karena menderita penyakit HIV-AIDS. Mereka yang tinggal di kampung hanya yang tua-tua, umur lima puluhan tahun, yang tidak kuat bekerja di ladang. Masalah terbesar di wilayah ini, air. Kesulitan air luar biasa. Ada dua sumber air, di Ama Hale dan Liu Mauk, sudah disurvey dan bisa memenuhi kebutuhan seluruh penduduk di Kecamatan ini, tapi sampai tahun 2018, hasil survey itu belum direalisasi.

Seorang tokoh Masyarakat Kecamatan ini yang berkunjung ke Atambua, Bapak Moruk Ama (78 tahun) diwawancara pada tanggal 15 Februari 2019, "Bapak, bilang hidup di kampung itu susah. Tapi banyak orang masih ada di sana. Apa yang buat mereka bertahan?"

Diberi jawaban,

"Yah, kita punya leluhur ada kubur di sana. Bagaimana kita bisa tinggalkan? Biar ke kota, biar merantau, pasti akan kembali. Hidup susah di kampung itu susah beras, susah pakaian, tapi keluarga ada untuk baku tolong. Ikatan keluarga kita kuat. Tidak pernah ada yang menderita sendiri. Susah samasama susah, senang sama-sama senang. Adat kita masih kuat. Rumah adat ikat kita. Pesta-pesta adat ikat kita. Kita senang tinggal di desa kita".

Dari dua ungkapan ini dan pengamatan peneliti, masyarakat Suku Buna' di Kecamatan Lamaknen Selatan ini bertahan hidup di sana, mampu menahan terpaan kesulitan ekonomi, bukan hanya oleh ketahanan fisik dan psikis melulu, tetapi harus ada dasar lain yang melatar-belakangi ketahanan hidup ini. Dasar lain itu apa saja? Penulis mempunyai asumsi, ketahanan itu 
terletak pada keterikatan yang erat antara masyarakat dengan tempat tinggal dan antara mereka dengan mereka. Keterikatan inilah yang penulis cari dan hasilnya penulis kemukakan dalam makalah ini.

\section{Analisis hasil penelitian: Nafsu sangat dominan}

1. Nafsu untuk membangun sangat dominan demi mengejar kebutuhan hidup sehari-hari. Pembangunan yang dilaksanakan oleh Masyarakat di Lamaknen Selatan dilaksanakan ternyata lebih terdorong oleh Nafsu untuk memenuhi kebutuhan sehari-hari tanpa didukung oleh Nalar, pengetahuan dan ketrampilan yang memadai. Berarti pembangunan di segala bidang kehidupan masyarakat lebih didorong oleh kepentingan untuk menggarap, memiliki dan memakai potensi lingkungan tanpa menampilkan kajian Nalar yang masuk akal. Naluri untuk mempertenggangkan kepentingan sesama kurang diperhitungkan. Nurani diabaikan sehingga masyarakat merasa tidak bersalah bahwa merambah hutan lindung dan merusak lingkungan yang merugikan kehidupan secara keseluruhan dianggap sebagai hal yang biasa dan bisa dibuat sesuka hati.

Hal ini dibuktikan dengan hasil dialog yang menyatakan bahwa $62 \%$ pembangun (pemimpin) mementingkan Nafsu. Pernyataan ini berlaku untuk masyarakat yang dipimpin, membangun lebih mengikuti dorongan Nafsu dan kurang memperhitungkan Nalar, Naluri dan Nurani.

2. Nalar dalam arti pemahaman dan penggunaan iptek kurang dipakai dalam membangun sehingga hasil yang diperoleh sangat minim. Pertanian dan peternakan tetap dilaksanakan secara tradisional, paling tidak 50 tahun lalu sewaktu peneliti masih kanak-kanak, cara bertani dan beternak masih sama sampai sekarang.

3. Naluri dalam arti perwujudan kenyamanan dan kedamaian dengan tetangga dan alam sekitar sangat diabaikan. Tanah diperebutkan tanpa mengakui hak warisan leluhur. Pertengkaran soal tanah sering terjadi.
4. Nurani dalam arti rasa hormat kepada sesama sudah sangat luntur. Rasa sakral yang begitu kuat tertanam dalam hati masyarakat sebagai warisan leluhur, sudah tidak dipandang sebagai kewajiban yang harus ditaati. Hutan keramat, sumber air sakral, bukit pemali, batu bertuah, dan larangan-larangan tradisional seperti tidak boleh memotong ranting pohon di hutan sakral, sudah dianggap sebagai kepercayaan kuno yang sudah harus ditinggalkan. Akibatnya penggarapan alam lingkungan sekitar tidak lagi dibatasi oleh rasa hormat yang tertanam dalam nurani masyarakat Suku Buna' di Kecamatan Lamaknen Selatan.

Berdasarkan analisis ini, masyarakat membangun sesuai selera mereka yang penuh nafsu tak terkendali dalam segala keterbatasan tanpa ada lagi pengkajian nalar, pertimbangan naluri dan permenungan nurani. Pembangunan yang dilaksanakan oleh manusia sebagai pembangun, lebih terdorong oleh Nafsu untuk memiliki, menguasai dan memakai hasil pembangunan.

Merusak lingkungan hidup kurang diperhitungkan. Nafsu pembangun itu menjadi tujuan jangka pendek. "Pokoknya ada. Apa pun yang terjadi, harus dilaksanakan. Yang penting terjadi. Saya yang berkuasa". Inilah ungkapan-ungkapan 'emas' dari para pembangun yang utamakan Nafsu tanpa dikaji oleh Nalar dan tanpa dipertimbangkan oleh Naluri serta kurang dikendali oleh Nurani.

Nafsu mendorong untuk menguasai, menggarap, menikmati hasil pegelolaan lingkungan. Nalar seharusnya diberi tempat untuk mengkaji benar tidaknya proses dan manfaat pembangunan. Naluri menjadi pertimbangan kepentingan sesama manusia baik yang sekarang ada maupun generasi mendatang. Nurani harus menjadi kendali untuk seluruh aktivitas pembangunan, apakah mempunyai nilai baik atau buruk bagi manusia dengan mengacu pada Kehendak Pencipta Sang Maha-Ada Yang mengadakan segala sesuatu.

Keempat unsur dalam diri manusia ini, NAFSU + NALAR + NALURI + NURANI harus disatu-padukan serta-merta dan 
serempak dalam segala macam upaya manusia yang dinamakan pembangunan.

Ada empat paradigma pembangunan berdasarkan 'kwadran bele':

1. Kalau Nafsu terlalu diutamakan tanpa memperhatikan kajian Nalar dan pertimbangan Naluri serta pengendalian Nurani, pasti setiap upaya pembangunan akan membawa kehancuran yang tak terpulihkan.

2. Kalau Nalar terlalu diutamakan tanpa memperhatikan perhitungan Nafsu dan kajian Nalar serta pertimbangan Nurani, pasti setiap upaya pembangunan akan membawa penyimpangan yang berada di luar akal sehat.

3. Kalau Naluri terlalu diutamakan tanpa memperhatikan perhitungan Nafsu yang matang dan kajian Nalar serta pertimbangan Nurani, pasti upaya pembangunan akan terarah kepada kepentingan diri dan para kolega serta kroni yang merugikan sesama manusia secara keseluruhan.

4. Kalau Nurani terlalu diutamakan tanpa memperhatikan perhitungan Nafsu dan kajian Nalar serta pertimbangan Naluri, maka upaya pembangunan dan hasilnya akan mengalami kemandegan karena pembangun menjadi serba hatihati dan ragu-ragu serta takut bertindak dengan melihat alam serba suci.

Maka empat unsur pribadi Manusia, NAFSU + NALAR + NALURI + NURANI harus ditampilkan secara seimbang agar upaya pembangunan dan hasilnya benar-benar manusiawi tanpa menimbulkan malapetaka bagi kelangsungan keutuhan dan kehidupan manusia di alam semesta ini.

Dalam pembangunan di Desa, masyarakat Desa paling nyata dilihat bukan berdasarkan Kepala Keluarga, tetapi berdasarkan kesatuan warga Dusun. Ikatan warga di Dusun sangat kuat. Mudah diarahkan untuk berbagai kegiatan. Jenisjenis pekerjaan di desa seperti pertanian, peternakan, kerajinan rumah tangga, mudah terdata melalui data dan fakta lapangan di dusun. Kepala Dusun berperan penting. Dana desa dialokasikan berdasarkan kebutuhan nyata (real) di dusun.

Kepala Desa sebagai koordinator untuk menyatu-padukan gerak langkah pembangunan masyarakat di dusun. Di dusun hasil produksi dibedakan untuk dikonsumsi langsung atau dijual untuk mendapatkan uang. Hasil dikumpulkan di dusun dan dijual ke pasar secara terpadu melalui petugas khusus yang dipilih dan dipercayai. Tidak perlu setiap warga menjual hasilnya ke pasar. Sistim koperasi dusun dilatih dan dipraktekkan. Masyarakat tidak perlu memboros waktu untuk memasarkan hasil kerjanya.

\section{KESIMPULAN}

Masyarakat di Kecamatan Lamaknen Selatan dapat didorong untuk membangun dirinya dalam memanfaatkan situasi nyata mereka dengan menerapkan 'kwadran bele' menjadi satu pola yang peneliti namakan 'pola dusun'. Dusun menjadi utama karena masyarakat desa terhimpun secara sangat akrab di tingkat dusun. Masyarakat diajak untuk berembug dan merancang pembangunan dusun mereka dengan mendata potensi lingkungan alam mereka lalu merumuskan: 1. kebutuhan mereka meliputi apa saja (Nafsu); 2. ilmu dan teknologi apa yang akan digunakan (Nalar); menghimpun segala sumber daya manusia, tua-muda, laki-perempuan (Naluri); penyadaran rasa rasa kemanusiaan dan cinta lingkungan yang dapat dipertanggungjawabkan di depan Pencipta (Nurani).

Pendamping yang handal dibutuhkan dan dana dialokasikan berdasarkan hasil rembug dusun ini. Cita-cita untuk hidup sejahtera dapat terwujud, membangun dengan mencintai Lingkungan Hidup.

\section{Pola Dusun}

Dalam rembug pembangunan di dusun, disusun rencana sesuai urutan berikut.

1. Nafsu: kebutuhan warga dusun didata.

2. Nalar: teknologi dipelajari dan diterapkan sesuai kemampuan warga dusun.

3. Naluri: kerja kelompok dalam dusun, diversifikasi tenaga kerja: lakilaki/perempuan, orang tua/ orang muda, jenjang pendidikan.

4. Nurani: peningkatan watak cinta lingkungan warga dusun melalui penyadaran tentang adat-istiadat dan agama. 
Dengan menerapkan teori 'kwadran bele' ini dalam pembangunan, era 4,0 sampai 7,0 dapat dimasuki tanpa menghancurkan kemanusiaan.

\section{DAFTAR PUSTAKA}

Antonius, B. (2011). Nurani orang Buna': Spiritual capital dalam pembangunan. Kupang: Yayasan Gita Kasih,.

Black, A. J., \& Champion, J. D. (2009). Metode \& masalah penelitian sosial. Bandung: PT Refika Aditama.

BPS Kabupaten Belu. (2018).

Bungin, B. (Ed.). (2011). Metodologi penelitian kualitatif. Jakarta: RajaGrafindo Persada.

Gunawan, I. (2013). Metode penelitian kualitatif, teori dan praktek. Jakarta: PT Bumi Aksara,

Hasbullah, J. (2006). Social capital. Jakarta: MR-United Press.

Makawimbang, H. F. (2016). Kompilasi peraturan perundang-undangan tentang desa, sistem pengelolaan dan tanggung jawab dana desa. Jakarta: Libri.

Maryaeni. (2005). Metodologi penelitian kebudayaan. Jakarta: PT Bumi Aksara.

Marzali, A. (2009). Antropologi \& pembangunan Indonesia. Jakarta: Kencana.

Meyer, S. D. et.al. (2002). Social movements: Identity, culture, and the state. Oxford University Press.

Ormeling, F. J. (1957). The Timor problem. Djakarta: J.B. Wolters - Groningan.

Widianarko, B. (2011). Membumikan etika lingkungan. Yogyakarta: Kanisius.

Yanuar, I. (2012). Metode penelitian sosial kualitatif. Bandung: Aditama.

Zohar, D., \& Marshall, I. (2005). Spiritual capital. Bandung: PT Mirzan Pustaka. 
Antonius / Nafsu Berlebihan Pembangun Merusak Lingkungan Hidup ... 